\title{
Non-Performing Loans Portfolio in The Banking Sector of Bangladesh and Recovery Status: A Study on Rangpur Region
}

\author{
Mst. Nishrat Zaman \\ Assistant Professor, Dept. of Management Studies, Begum Rokeya University, Rangpur
}

\begin{abstract}
Non-performing loan (NPL) is the recent burning issue and great challenge for the banking sector. Banks play very important role for economic enhancement of a country. They provide funds to the deficit units for business, production \& development activities. But when banks fail to recover loan, then it becomes to non-performing loan. In Bangladesh, state owned commercial banks (SOCBs) are the worst and private commercial banks are lest sufferers from non-performing loan. This paper tries to represent the non-performing loan status of banks operating in seven districts under Rangpur division. This study is descriptive and based on secondary sources. The aim of this paper is to present the non-performing loan scenario and recovery status of the mentioned area and to provide recommendations for mitigating non-performing loan in Rangpur region.
\end{abstract}

Keywords: Non-performing loan(NPL), Economic enhancement, State owned Commercial Banks (SOCBs), Private Commercial Bank (PCBs) etc.

DOI: $10.7176 / \mathrm{EJBM} / 12-7-09$

Publication date:March $31^{\text {st }} 2020$

\section{INTRODUCTION}

Non-performing loans refer to those loans from which banks no longer receive interest and/or installment payments as scheduled. It is a loan for which the principal or interest payment remained overdue for a period of time. A NPL is either in default or close to being default. A loan is non-performing when payments of interest and principal are past due by 90 days or more, or at least 90 days of interest payments have been capitalized, refinanced or delayed by agreement, or payments are less than 90 days overdue, but there are other good reasons to doubt that payments will be made in full (IMF 2005). NPLs are known as Non-performing because the loan ceases to "perform" or generate income for the bank. Choudhury (2002) stated that the non-performing loan is not a "uniclass" but rather a "multiclass" concept, which means that NPLs can be classified into different varieties usually based on the "length of overdue" of the said loans. NPLs can be viewed as a typical byproduct of financial crisis. They are not a main product of the lending function but rather an accidental occurrence of the lending process, one that has enormous potential to deepen the severity and duration of financial crisis and to complicate macroeconomic management (Woo,2000).

The performance of the financial sector of our country heavily depends on the performance of banks. It is known to all that the entire non-performing loans shrink the profitability of banks. NPL don't contribute to the income of the banks, rather these loans decrease the loan able fund of the banks. NPL also stops the recycling banking business.

A poor banking system can't help the economic development of a country. Despite massive injection of loans to the national economy, the contribution of financial sector to the Gross Domestic Product (GDP) remained at dismal level. This laden loan contributes to GDP by unhealthy and inefficient financial situation. Non-professional handling of assets both by SOCBs and PCBs was reported as the main reasons for the accumulation of loan default problem in Bangladesh (Alam and Jahan, 1999).

Bangladesh Bank (BB) as a central regulatory authority of banks in Bangladesh plays important role in monitoring and supervision by providing guidelines, circulars and circular letters time to time. BB provides circular on single borrower exposure limit, syndicate financing, bridge financing etc. Now banks are not permitted to approve large loans in favor of any individual or group of borrowers in excess of 50 percent of their total capital. Loans, which have been classified as bad/loss for 5 years or more that must be written off by the banks in order to clean the defaulted loan from their affairs. Hundred percentage provisions have been kept against that write off loan.

\section{LITERATURE REVIEW}

Banik and Das (2015) concluded that though percentage of classified loan is increasing among commercial banks, the amount of POCL is higher in state -owned commercial banks than that of private commercial banks. Islam (2012), in a study on Bangladesh House Building Finance Corporation found that 97.6 percent of the variability in the volume of classified loans can be explained by total advances, provisions, legal charges and spread. The variable legal charge was found to be statistically insignificant. Parvin (2011) stated that NPLs in Bangladesh reveals that the banking sector of Bangladesh is yet to get out of its NPL mess, although substantial improvement has been noticed recently. Adhikary (2006) found immediate consequence of large amount of 
NPLs in the banking system is bank failure as well as economic slowdown. The causes of non-performing loans are usually attributed to the lack of effective monitoring and supervision on the part of banks, lack of effective lenders' recourse, weakness of legal infrastructure, and lack of effective debt recovery strategies.

Ezaz (2006) revealed their study that the loan default is quite enormous in the banking sector. They analyzed the issues governing the recovery rate and procedure with respect to Islamic Banking while comparing with the conventional baking principles amongst NCBs, PCBs and ICB. Hou (2001) argued that there is no global standard to define non-performing loans at the practical level variations exist in terms of the classification system, the scope, and contents. Such problem potentially adds to disorder and uncertainty in the NPL issues. Non-performing loans have non-linear negative effect on banks' lending behavior.

Afroz \& Uddin (2010) found in their empirical study that from the views of employees of the banks those steps taken to prevent loan classification and provisioning requirements are not sufficient; due to lack of persuasion the rate of willful defaulters is high. Hassan \& Reza (1997) prepared a study on comparison of commercial Banks of Bangladesh in respect to several dimension of deposit, they identified, in 1983 PCBs were allowed to start the banking activities for the betterment than the services of NCBs. Moti et al. (2012) conducted a study on credit management and found that a key requirement for effective credit management is the ability to intelligently and efficiently manage customer credit lines. Sikder et al. (2006) studied on the operational performance of the Bangladesh Krishi Bank and evaluated in terms of some indicators viz. deposit mobilization, loan disbursement, loan recovery and profit and found that the operational performance of the bank is very poor due to some lending procedural drawbacks reaching the profit target fixed by the authority concerned.

Lots of researches have been made on non-performing loan. Researchers identified some variables which are related to non-performing loan. Research on comparative study between SOCBs and PCBs are made as well. In this paper researcher will try to highlight NPLs scenario of banks operating seven districts of Rangpur division. The present paper has given attention more to select Rangpur division because lots of research has been conducted but exclusively for Rangpur division yet no research has been done. For availability of data seven districts of Rangpur has been chosen. The study tries to show the present status through a descriptive analysis relating to NPLs of the selected area.

\section{OBJECTIVES OF THE STUDY}

The major objective of this study is to represent the overall scenario of total loan disbursement, NPLs \& recovery status of banks in the seven districts of Rangpur region. This study also attempts to achieve the following specific objectives:

- $\quad$ to give an overview of the recovery status of non-performing loans;

- to analyze legal status to recover loans from the defaulters;

- $\quad$ to compare the NPLs scenario between SOCBs and Private PCBs; and

- to recommend some suggestions in recovering these NPLs

\section{METHODOLOGY}

This paper has been made based on secondary sources like research works of individuals, different publications, journal of different institutions, Bangladesh Bank survey etc. Forty one commercial banks both from state owned and private have been selected purposively from the seven districts of Rangpur division except Gaibandha district to represent the NPLs and their recovery system.

\section{DISCUSSION, ANALYSIS AND FINDINGS}

Rangpur, a district of northern region, has economic value for its contribution to the development of Bangladesh by supplying valuable resources. There are approximately 41 banks operating in Rangpur division. Most of the banks do have several branches. The data used here are consolidated data of the bank branches of those 41 banks. Here data are categorized in various ways and a discussion has been given after the data is captured in a table. 
Table-1: Total loan disbursement and classified loan (in lac taka.)

\begin{tabular}{|c|c|c|c|c|}
\hline S.N & Name of the Bank & $\begin{array}{c}\text { Total Loan } \\
\text { Disbursement }\end{array}$ & $\begin{array}{c}\text { Amount of } \\
\text { Classified loan }\end{array}$ & $\begin{array}{c}\text { Classified } \\
\text { loan } \%\end{array}$ \\
\hline 1 & AB Bank & 37437.65 & 503.74 & $1.35 \%$ \\
\hline 2 & Agrani Bank & 100816.56 & 9712.73 & $9.63 \%$ \\
\hline 3 & Al-Arafah Islami Bank & 32837.83 & 2622.52 & $7.99 \%$ \\
\hline 4 & Bank Asia & 6938.02 & 302.18 & $4.36 \%$ \\
\hline 5 & Basic Bank & 20918.71 & 10757.07 & $51.42 \%$ \\
\hline 6 & BDBL & 12526.62 & 9193.92 & $73.40 \%$ \\
\hline 7 & Brac Bank & 35797.60 & 1399.75 & $3.91 \%$ \\
\hline 8 & Commerce Bank & 2219.76 & 1319.67 & $59.45 \%$ \\
\hline 9 & Dhaka Bank & 13458.91 & 1432.95 & $10.65 \%$ \\
\hline 10 & Dutch Bangla Bank & 4877.63 & 120.11 & $2.46 \%$ \\
\hline 11 & Estern Bank & 4141.02 & 119.26 & $2.88 \%$ \\
\hline 12 & Exim Bank & 12124.40 & 2662.46 & $21.96 \%$ \\
\hline 13 & First Security Islami Bank & 1297.60 & 0 & $0.00 \%$ \\
\hline 14 & IFIC Bank & 18210.81 & 1062.20 & $5.83 \%$ \\
\hline 15 & Islami Bank & 210634.80 & 2610.00 & $1.24 \%$ \\
\hline 16 & Jamuna Bank & 21106.07 & 2984.91 & $14.14 \%$ \\
\hline 17 & Janata Bank & 75089.48 & 8442.53 & $11.24 \%$ \\
\hline 18 & Kormoshantan Bank & 8989.54 & 1096.14 & $12.19 \%$ \\
\hline 19 & Meghna Bank & 4419.49 & 0 & $0.00 \%$ \\
\hline 20 & Mercantile Bank & 25385.12 & 998.32 & $3.93 \%$ \\
\hline 21 & Mutual Trust Bank & 18011.70 & 1234.33 & $6.85 \%$ \\
\hline 22 & National Bank & 37510.29 & 2790.59 & $7.44 \%$ \\
\hline 23 & NCC Bank & 10982.58 & 2243.66 & $20.43 \%$ \\
\hline 24 & NRB Commercial Bank & 953.61 & 0 & $0.00 \%$ \\
\hline 25 & One Bank & 5038.81 & 5.07 & $0.10 \%$ \\
\hline 26 & Premier Bank & 2943.00 & 335.96 & $11.42 \%$ \\
\hline 27 & Prime Bank & 13497.95 & 645.19 & $4.78 \%$ \\
\hline 28 & Pubali Bank & 36071.63 & 5006.08 & $13.88 \%$ \\
\hline 29 & Rajshahi Krishi Unnayan Bank & 235743.77 & 64356.67 & $27.30 \%$ \\
\hline 30 & Rupali Bank & 64557.62 & 14114.99 & $21.86 \%$ \\
\hline 31 & Shahjalal Islami Bank & 17310.40 & 2537.18 & $14.66 \%$ \\
\hline 32 & Social Islami Bank & 18688.25 & 457.53 & $2.45 \%$ \\
\hline 33 & Sonali Bank Ltd. & 271558.00 & 24541.00 & $9.04 \%$ \\
\hline 34 & South Bangla Bank & 6256.80 & 0 & $0.00 \%$ \\
\hline 35 & Southeast Bank & 8341.34 & 815.00 & $9.77 \%$ \\
\hline 36 & Standard Bank & 43288.62 & 1741.35 & $4.02 \%$ \\
\hline 37 & The City Bank & 19662.66 & 2817.66 & $14.33 \%$ \\
\hline 38 & Trust Bank & 30615.89 & 625.56 & $2.04 \%$ \\
\hline 39 & UCBl & 7388.01 & 659.43 & $8.93 \%$ \\
\hline 40 & Union Bank & 1051.00 & 0 & $0.00 \%$ \\
\hline 41 & Uttara Bank & 34806.29 & 3071.38 & $8.82 \%$ \\
\hline
\end{tabular}

Source: Quarterly review, BB 2017

Table 1 depicts that Sonali Bank is at the top position in loan disbursement in Rangpur division. Rajshahi Krishi Unnayan Bank (RAKUB) is at the second position whereas Islami Bank Bangladesh Ltd (IBBL) is at the third position. Sonali bank has disbursed almost 271558.00 lac taka at the end of June 2017. RAKUB disbursed almost 2357.43 crore taka and IBBL disbursed 210634.80 lac taka at the same time.

In terms of NPL, RAKUB is at the top position whereas Sonali and Rupali Bank is at the second and third position. RAKUB's NPL amount is 64356.67 lac, Sonali Bank's NPL amount is 24541.00 lac and Rupali Bank has 14114.99 lac taka. But percentage of NPL in terms of total loan disbursement, BDBL is at the top position whereas Bangladesh Commerce bank (BCB) is at the second and BASIC Bank is at the third position. BDBL, $\mathrm{BCB}$ and Basic bank's classified loan is almost $73.40 \%, 59.45 \%$ and $51.42 \%$ respectively.

In the above table, few banks have no NPL because they newly operating in Rangpur division. They newly disburse loan to the clients. For being NPL, time is most important factor. 
Table 2: Comparison of two quarter's loan disbursement and NPL (in lac taka)

\begin{tabular}{|c|c|c|c|c|c|c|c|}
\hline \multirow[b]{2}{*}{$S . N$} & \multirow[b]{2}{*}{ Name of the Bank } & \multicolumn{3}{|c|}{$\begin{array}{c}\text { Last quarter } \\
\text { (January-March/2017) }\end{array}$} & \multicolumn{3}{|c|}{$\begin{array}{l}\text { Present quarter } \\
\text { (April-June/17) }\end{array}$} \\
\hline & & Total Loan & $\begin{array}{l}\text { Classified } \\
\text { loan }\end{array}$ & $\%$ & Total Loan & $\begin{array}{l}\text { Classified } \\
\text { loan }\end{array}$ & $\%$ \\
\hline 1 & Sonali & 262916 & 24792 & $9.43 \%$ & 271558 & 24541 & $9.04 \%$ \\
\hline 2 & Agrani & 96285.68 & 11088.23 & $11.52 \%$ & 100816.56 & 9712.73 & $9.63 \%$ \\
\hline 3 & IFIC & 24577.98 & 1728.61 & $7.03 \%$ & 18210.81 & 1062.2 & $5.83 \%$ \\
\hline 4 & $\mathrm{AB}$ & 39408.79 & 373.4 & $0.95 \%$ & 37437.65 & 503.74 & $1.35 \%$ \\
\hline 5 & One & 4196.57 & 3.46 & $0.08 \%$ & 5038.81 & 5.07 & $0.10 \%$ \\
\hline 6 & Trust & 28027.32 & 554.98 & $1.98 \%$ & 30615.89 & 625.56 & $2.04 \%$ \\
\hline 7 & DBBL & 6200.94 & 155.24 & $2.50 \%$ & 4877.63 & 120.11 & $2.46 \%$ \\
\hline 8 & Brac & 15492 & 728.97 & $4.71 \%$ & 35797.6 & 1399.75 & $3.91 \%$ \\
\hline 9 & Mercantile & 23497.82 & 927.68 & $3.95 \%$ & 25385.12 & 998.32 & $3.93 \%$ \\
\hline 10 & Standard & 31256.57 & 1052.96 & $3.37 \%$ & 43288.62 & 1741.35 & $4.02 \%$ \\
\hline 11 & Meghna & 2454.74 & 0 & $0.00 \%$ & 4419.49 & 0 & $0.00 \%$ \\
\hline 12 & EBL & 3858.65 & 51.54 & $1.34 \%$ & 4141.02 & 119.26 & $2.88 \%$ \\
\hline 13 & Bank Asia & 6277 & 278.19 & $4.43 \%$ & 6938.02 & 302.18 & $4.36 \%$ \\
\hline 14 & Prime & 11992.33 & 620.43 & $5.17 \%$ & 13497.95 & 645.19 & $4.78 \%$ \\
\hline 15 & Uttara & 31043.76 & 2709.26 & $8.73 \%$ & 34806.29 & 3071.38 & $8.82 \%$ \\
\hline 16 & MTBL & 18460.56 & 1098.09 & $5.95 \%$ & 18011.7 & 1234.33 & $6.85 \%$ \\
\hline 17 & NBL & 37088.19 & 2799.62 & $7.55 \%$ & 37510.29 & 2790.59 & $7.44 \%$ \\
\hline 18 & Southeast & 7764.01 & 953.31 & $12.28 \%$ & 8341.34 & 815 & $9.77 \%$ \\
\hline 19 & UCBL & 8174.65 & 825.3 & $10.10 \%$ & 7388.01 & 659.43 & $8.93 \%$ \\
\hline 20 & South Bangla & 4669.25 & 0 & $0.00 \%$ & 6256.8 & 0 & $0.00 \%$ \\
\hline 21 & NRB Commercial & 1047.65 & 0 & $0.00 \%$ & 953.61 & 0 & $0.00 \%$ \\
\hline 22 & Islami & 192430 & 2179.7 & $1.13 \%$ & 210634.8 & 2610 & $1.24 \%$ \\
\hline 23 & Al-Arafah Islami & 35196.39 & 2685.22 & $7.63 \%$ & 32837.83 & 2622.52 & $7.99 \%$ \\
\hline 24 & Social Islami & 16307.47 & 243.48 & $1.49 \%$ & 18688.25 & 457.53 & $2.45 \%$ \\
\hline 25 & First Security & 1293.99 & 0 & $0.00 \%$ & 1297.6 & 0 & $0.00 \%$ \\
\hline 26 & Union & 101.81 & 0 & $0.00 \%$ & 1051 & 0 & $0.00 \%$ \\
\hline 27 & Janata & 72613 & 9492.85 & $13.07 \%$ & 75089.48 & 8442.53 & $11.24 \%$ \\
\hline 28 & Rupali & 59325.16 & 12558.1 & $21.17 \%$ & 64557.62 & 14114.99 & $21.86 \%$ \\
\hline 29 & RAKUB & 223625.51 & 44399.06 & $19.85 \%$ & 235743.77 & 64356.67 & $27.30 \%$ \\
\hline 30 & Kormoshantan & 8888.35 & 1088.44 & $12.25 \%$ & 8989.54 & 1096.14 & $12.19 \%$ \\
\hline 31 & Basic & 20841.48 & 9598.25 & $46.05 \%$ & 20918.71 & 10757.07 & $51.42 \%$ \\
\hline 32 & BDBL & 12905.92 & 9125.28 & $70.71 \%$ & 12526.62 & 9193.92 & $73.40 \%$ \\
\hline 33 & Jamuna & 23199.92 & 2189.66 & $9.44 \%$ & 21106.07 & 2984.91 & $14.14 \%$ \\
\hline 34 & The City & 17281.35 & 1623.47 & $9.39 \%$ & 19662.66 & 2817.66 & $14.33 \%$ \\
\hline 35 & Dhaka & 12539.34 & 1529.96 & $12.20 \%$ & 13458.91 & 1432.95 & $10.65 \%$ \\
\hline 36 & $\mathrm{NCC}$ & 11687.1 & 2087.66 & $17.86 \%$ & 10982.58 & 2243.66 & $20.43 \%$ \\
\hline 37 & Pubali & 35564.06 & 3855.57 & $10.84 \%$ & 36071.63 & 5006.08 & $13.88 \%$ \\
\hline 38 & Commerce Bank & 2234.78 & 1329.67 & $59.50 \%$ & 2219.76 & 1319.67 & $59.45 \%$ \\
\hline 39 & Premier & 2908 & 381.1 & $13.11 \%$ & 2943 & 335.96 & $11.42 \%$ \\
\hline 40 & Shahjalal Islami & 14965.7 & 2351.6 & $15.71 \%$ & 17310.4 & 2537.18 & $14.66 \%$ \\
\hline 41 & Exim & 11177.1 & 2677.98 & $23.96 \%$ & 12124.4 & 2662.46 & $21.96 \%$ \\
\hline
\end{tabular}

Source: Quarterly review, BB 2017

Table 2 shows the amount of loan disbursement and NPL status of the banks in first quarter and second quarter of 2017. BDBL, Commerce bank and Basic bank has the most NPL in both quarters. Few banks NPL amount decreases and few banks NPL increases from first quarter to second quarter. EBL's classified loan increased sharply from first quarter to second quarter. EBL's classified loan is $1.34 \%$ in first quarter whereas NPL increased to $2.88 \%$ in second quarter. NCC bank's NPL also increased from first quarter to second quarter. NCC bank's NPL is $17.86 \%$ in first quarter whereas NPL increased to $20.43 \%$ in second quarter. The City Bank's NPL increased sharply from first quarter to second quarter. City Bank's NPL increased from 9.39\% to $14.33 \%$. Jamuna Bank's NPL also increased from $9.44 \%$ to $14.14 \%$. The percentage of NPL into the total loan in first quarter is maximum $70.71 \%$ and minimum $0.08 \%$ and in second quarter is maximum $73.40 \%$ and minimum $0.10 \%$. The table also represents the recovery rate of NPL on quarterly basis. 19 banks NPL have increased, 17 
banks have decreased and 5 banks NPL remain unchanged. The amount of NPL is highest (Taka.64356.67 lac) of RAKUB and lowest (Taka.5.07 lac) of One Bank limited.

Table 3: Recovery of NPL (in lac taka)

\begin{tabular}{|c|c|c|c|c|}
\hline S.N & Name of the Bank & $\begin{array}{c}\text { Amount of } \\
\text { Classified loan }\end{array}$ & $\begin{array}{l}\text { Recovery } \\
\text { Amount }\end{array}$ & Recovery \% \\
\hline 1 & Sonali Bank Ltd. & 24541.00 & 2255.00 & $9.19 \%$ \\
\hline 2 & Agrani Bank & 9712.73 & 2443.45 & $25.16 \%$ \\
\hline 3 & IFIC Bank & 1062.20 & 86.94 & $8.18 \%$ \\
\hline 4 & AB Bank & 503.74 & 0.15 & $0.03 \%$ \\
\hline 5 & One Bank & 5.07 & 0.63 & $12.43 \%$ \\
\hline 6 & Trust Bank & 625.56 & 11.93 & $1.91 \%$ \\
\hline 7 & Dutch Bangla Bank & 120.11 & 1.10 & $0.92 \%$ \\
\hline 8 & Brac Bank & 1399.75 & 55.28 & $3.95 \%$ \\
\hline 9 & Mercantile Bank & 998.32 & 46.23 & $4.63 \%$ \\
\hline 10 & Standard Bank & 1741.35 & 51.13 & $2.94 \%$ \\
\hline 11 & Meghna Bank & 0 & 0 & $0.00 \%$ \\
\hline 12 & Estern Bank & 119.26 & 2.84 & $2.38 \%$ \\
\hline 13 & Bank Asia & 302.18 & 0 & $0.00 \%$ \\
\hline 14 & Prime Bank & 645.19 & 4.98 & $0.77 \%$ \\
\hline 15 & Uttara Bank & 3071.38 & 88.30 & $2.87 \%$ \\
\hline 16 & Mutual Trust Bank & 1234.33 & 11.41 & $0.92 \%$ \\
\hline 17 & National Bank & 2790.59 & 41.38 & $1.48 \%$ \\
\hline 18 & Southeast Bank & 815.00 & 2.57 & $0.32 \%$ \\
\hline 19 & UCBl & 659.43 & 165.92 & $25.16 \%$ \\
\hline 20 & South Bangla Bank & 0 & 0 & $0.00 \%$ \\
\hline 21 & NRB Commercial Bank & 0 & 0 & $0.00 \%$ \\
\hline 22 & Islami Bank & 2610.00 & 392.60 & $15.04 \%$ \\
\hline 23 & Al-Arafah Islami Bank & 2622.52 & 59.63 & $2.27 \%$ \\
\hline 24 & Social Islami Bank & 457.53 & 0.37 & $0.08 \%$ \\
\hline 25 & First Security Islami Bank & 0 & 0 & $0.00 \%$ \\
\hline 26 & Union Bank & 0 & 0 & $0.00 \%$ \\
\hline 27 & Janata Bank & 8442.53 & 1135.65 & $13.45 \%$ \\
\hline 28 & Rupali Bank & 14114.99 & 706.15 & $5.00 \%$ \\
\hline 29 & Rajshahi Krishi Unnayan Bank & 64356.67 & 4334.74 & $6.74 \%$ \\
\hline 30 & Kormoshantan Bank & 1096.14 & 57.11 & $5.21 \%$ \\
\hline 31 & Basic Bank & 10757.07 & 12.25 & $0.11 \%$ \\
\hline 32 & BDBL & 9193.92 & 370.20 & $4.03 \%$ \\
\hline 33 & Jamuna Bank & 2984.91 & 54.76 & $1.83 \%$ \\
\hline 34 & The City Bank & 2817.66 & 75.40 & $2.68 \%$ \\
\hline 35 & Dhaka Bank & 1432.95 & 83.96 & $5.86 \%$ \\
\hline 36 & NCC Bank & 2243.66 & 32.89 & $1.47 \%$ \\
\hline 37 & Pubali Bank & 5006.08 & 450.25 & $8.99 \%$ \\
\hline 38 & Commerce Bank & 1319.67 & 0.02 & $0.00 \%$ \\
\hline 39 & Premier Bank & 335.96 & 242.93 & $72.31 \%$ \\
\hline 40 & Shahjalal Islami Bank & 2537.18 & 4.63 & $0.18 \%$ \\
\hline 41 & Exim Bank & 2662.46 & 77.55 & $2.91 \%$ \\
\hline
\end{tabular}

Source: Quarterly review, BB 2017

Table 3 expresses that total amount of NPL of banks and their recovery performance at the end of June 2017. The table also shows that RAKUB has the highest amount of NPL and the recovery as well. At the end of second quarter in 2017, RAKUB recovers 4334.74 lac taka, which is $6.74 \%$ of its NPL. Agrani Bank is at the second position. Agrani Bank recovers 2443.45 lac taka which is $25.16 \%$ of its NPL. Sonali Bank hold the third position in recovering classified loan and it is 2255.00 lac, which is $9.19 \%$ of its total NPL. Highest percentage of recovery done by Premier bank and it is 242.93 lac taka out of 335.96 lac taka. A very few number of banks recover double digit percentage while others recovery performance is single digit. The lowest amount of recovery done by $\mathrm{AB}$ Bank Limited which is $0.03 \%$ of its total NPL. 
Table 4: Status of law-suit of Banks (in lac taka)

\begin{tabular}{|c|c|c|c|c|c|c|c|c|c|}
\hline S.N & Banks Name & Number & Taka & Number & Taka & Number & Taka & Number & Taka \\
\hline 1 & Sonali & 3035 & 5436.57 & 23 & 36.00 & 40 & 113.82 & 3052 & 5514.39 \\
\hline 2 & Agrani & 1884 & 6699.82 & 43 & 70.67 & 34 & 35.25 & 1875 & 6664.40 \\
\hline 3 & IFIC & 13 & 997.98 & 1 & 86.82 & 1 & 36.08 & 13 & 947.24 \\
\hline 4 & $\mathrm{AB}$ & 2 & 184.29 & 0 & 0.00 & 0 & 0.00 & 2 & 184.29 \\
\hline 5 & One & 0 & 0.00 & 0 & 0.00 & 0 & 0.00 & 0 & 0.00 \\
\hline 6 & Trust & 14 & 75.88 & 1 & 2.04 & 8 & 42.18 & 21 & 116.02 \\
\hline 7 & DBBL & 2 & 16.13 & 0 & 0.00 & 0 & 0.00 & 2 & 16.13 \\
\hline 8 & Brac & 61 & 558.72 & 6 & 41.23 & 2 & 11.15 & 57 & 528.64 \\
\hline 9 & Mercantile & 4 & 186.38 & 0 & 0.00 & 0 & 0.00 & 4 & 186.38 \\
\hline 10 & Standard & 2 & 161.54 & 0 & 0.00 & 0 & 0.00 & 2 & 161.54 \\
\hline 11 & Meghna & 0 & 0.00 & 0 & 0.00 & 0 & 0.00 & 0 & 0.00 \\
\hline 12 & EBL & 16 & 102.27 & 0 & 0.00 & 1 & 5.92 & 17 & 108.19 \\
\hline 13 & Bank Asia & 2 & 288.37 & 0 & 0.00 & 0 & 0.00 & 2 & 288.37 \\
\hline 14 & Prime & 28 & 333.74 & 1 & 38.79 & 0 & 0.00 & 27 & 294.95 \\
\hline 15 & Uttara & 99 & 2455.80 & 2 & 219.87 & 4 & 124.25 & 101 & 2360.18 \\
\hline 16 & MTBL & 3 & 73.88 & 0 & 0.00 & 0 & 0.00 & 3 & 73.88 \\
\hline 17 & NBL & 16 & 3361.31 & 0 & 0.00 & 0 & 0.00 & 16 & 3361.31 \\
\hline 18 & Southeast & 1 & 192.73 & 0 & 0.00 & 0 & 0.00 & 1 & 192.73 \\
\hline 19 & UCBL & 2 & 620.55 & 0 & 0.00 & 0 & 0.00 & 2 & 620.55 \\
\hline 20 & South Bangla & 0 & 0.00 & 0 & 0.00 & 0 & 0.00 & 0 & 0.00 \\
\hline 21 & NRB Commercial & 0 & 0.00 & 0 & 0.00 & 0 & 0.00 & 0 & 0.00 \\
\hline 22 & Islami & 9 & 212.00 & 1 & 17.40 & 0 & 0.00 & 8 & 194.60 \\
\hline 23 & Al-Arafah & 7 & 1794.07 & 0 & 0.00 & 1 & 373.32 & 8 & 2167.39 \\
\hline 24 & SIBL & 1 & 258.31 & 0 & 0.00 & 0 & 0.00 & 1 & 258.31 \\
\hline 25 & First Security & 0 & 0.00 & 0 & 0.00 & 0 & 0.00 & 0 & 0.00 \\
\hline 26 & Union & 0 & 0.00 & 0 & 0.00 & 0 & 0.00 & 0 & 0.00 \\
\hline 27 & Janata & 1510 & 5708.11 & 16 & 59.23 & 34 & 484.10 & 1528 & 6132.98 \\
\hline 28 & Rupali & 478 & 3615.41 & 16 & 232.50 & 13 & 84.54 & 475 & 3467.45 \\
\hline 29 & RAKUB & 8885 & 10568.20 & 166 & 162.08 & 55 & 112.61 & 8774 & 10518.73 \\
\hline 30 & Kormoshantan & 737 & 374.46 & 33 & 30.28 & 22 & 23.90 & 726 & 368.08 \\
\hline 31 & Basic & 1 & 997.97 & 0 & 0.00 & 0 & 0.00 & 1 & 997.97 \\
\hline 32 & BDBL & 20 & 4770.60 & 0 & 0.00 & 1 & 2394.20 & 21 & 7164.80 \\
\hline 33 & Jamuna & 8 & 921.19 & 1 & 49.69 & 0 & 0.00 & 7 & 871.50 \\
\hline 34 & The City & 18 & 768.98 & 0 & 0.00 & 6 & 713.37 & 24 & 1482.35 \\
\hline 35 & Dhaka & 2 & 204.74 & 0 & 0.00 & 0 & 0.00 & 2 & 204.74 \\
\hline 36 & $\mathrm{NCC}$ & 26 & 2280.04 & 0 & 0.00 & 1 & 48.62 & 27 & 2328.66 \\
\hline 37 & Pubali & 15 & 3232.00 & 0 & 0.00 & 1 & 53.75 & 16 & 3285.75 \\
\hline 38 & Commerce & 0 & 0.00 & 0 & 0.00 & 0 & 0.00 & 0 & 0.00 \\
\hline 39 & Premier & 0 & 0.00 & 0 & 0.00 & 0 & 0.00 & 0 & 0.00 \\
\hline 40 & Shahjalal Islami & 27 & 3179.48 & 1 & 122.00 & 3 & 1687.59 & 29 & 4745.07 \\
\hline 41 & Exim & 15 & 2090.83 & 0 & 0.00 & 0 & 0.00 & 15 & 2090.83 \\
\hline
\end{tabular}

Source: Quarterly Review, BB 2017

Table 4 depicts the law-suit status of banks for recovery of defaulted loan from their defaulted borrower, how many suits are settled and how many new suit made and what is the claim amount of those suit. Banks made suit against their default borrower for recovering classified loan. Different types of suits can be made under different laws and act like certificate suit and orthorin suit. As per the categories of the loan banks made different suits. Banks made lots of suits for recovering their defaulted loan except BCB, Premier, One, Meghna, NRB, First Security, Union and South Bangla Agriculture \& Commerce bank. At the end of the second quarter in 2017, RAKUB has 8774 suits which is highest in number among all of the banks and its claim amount is 10518.73 lac taka. RAKUB gives a large number of agricultural loans to the farmers. The size of this loan is very small. For recovery of those loans RAKUB made a large number of suits. From the above table it is clear that state owned commercial banks have large number of suit compare to the private commercial banks. But by the few suits private commercial banks claim huge amount of taka. Private commercial banks loan portfolio is smaller in number than state owned commercial banks but they financed more than SOCBs. That's why when PCBs loans become classified and they suit a file against them the claim amount is very high. 
Table 5: List of banks classified loan above $10 \%$ (in lac taka.)

\begin{tabular}{|c|c|c|c|c|}
\hline S.N & Name of the Bank & Total Loan & Classified loan & $\%$ \\
\hline 1 & Janata & 75089.48 & 8442.53 & $11.24 \%$ \\
\hline 2 & Rupali & 64557.62 & 14114.99 & $21.86 \%$ \\
\hline 3 & RAKUB & 235743.77 & 64356.67 & $27.30 \%$ \\
\hline 4 & Kormoshantan & 8989.54 & 1096.14 & $12.19 \%$ \\
\hline 5 & Basic & 20918.71 & 10757.07 & $51.42 \%$ \\
\hline 6 & BDBL & 12526.62 & 9193.92 & $73.40 \%$ \\
\hline 7 & Jamuna & 21106.07 & 2984.91 & $14.14 \%$ \\
\hline 8 & The City & 19662.66 & 2817.66 & $14.33 \%$ \\
\hline 9 & Dhaka & 13458.91 & 1432.95 & $10.65 \%$ \\
\hline 10 & $\mathrm{NCC}$ & 10982.58 & 2243.66 & $20.43 \%$ \\
\hline 11 & Pubali & 36071.63 & 5006.08 & $13.88 \%$ \\
\hline 12 & Commerce & 2219.76 & 1319.67 & $59.45 \%$ \\
\hline 13 & Premier & 2943 & 335.96 & $11.42 \%$ \\
\hline 14 & Shahjalal Islami & 17310.4 & 2537.18 & $14.66 \%$ \\
\hline 15 & Exim & 12124.4 & 2662.46 & $21.96 \%$ \\
\hline
\end{tabular}

Source: Quarterly review, BB 2017

Table 5 represents the amount of total loan disbursement, NPL of those banks who have NPL more than $10 \%$. At the end of the second quarter of 2017, 15 banks have NPL more than $10 \%$ of their total loan outstanding. BDBL has the maximum NPL which was $73.40 \%$ and Dhaka Bank has the minimum NPL which was $10.65 \%$.

RAKUB has the highest amount of NPL and Premier Bank has the lowest amount of NPL.

Table 6: List of Bank's classified loan below 10\% (in lac taka.)

\begin{tabular}{|c|c|c|c|c|}
\hline \multirow[b]{2}{*}{ S.N } & \multirow[b]{2}{*}{ Name of the Bank } & \multicolumn{3}{|c|}{ Present quarter (April-June/17) } \\
\hline & & Total Loan & Classified loan & $\%$ \\
\hline 1 & Sonali & 271558.00 & 24541.00 & $9.04 \%$ \\
\hline 2 & Agrani & 100816.56 & 9712.73 & $9.63 \%$ \\
\hline 3 & IFIC & 18210.81 & 1062.2 & $5.83 \%$ \\
\hline 4 & $\mathrm{AB}$ & 37437.65 & 503.74 & $1.35 \%$ \\
\hline 5 & One & 5038.81 & 5.07 & $0.10 \%$ \\
\hline 6 & Trust & 30615.89 & 625.56 & $2.04 \%$ \\
\hline 7 & DBBL & 4877.63 & 120.11 & $2.46 \%$ \\
\hline 8 & Brac & 35797.6 & 1399.75 & $3.91 \%$ \\
\hline 9 & Mercantile & 25385.12 & 998.32 & $3.93 \%$ \\
\hline 10 & Standard & 43288.62 & 1741.35 & $4.02 \%$ \\
\hline 11 & Meghna & 4419.49 & 0 & $0.00 \%$ \\
\hline 12 & EBL & 4141.02 & 119.26 & $2.88 \%$ \\
\hline 13 & Bank Asia & 6938.02 & 302.18 & $4.36 \%$ \\
\hline 14 & Prime & 13497.95 & 645.19 & $4.78 \%$ \\
\hline 15 & Uttara & 34806.29 & 3071.38 & $8.82 \%$ \\
\hline 16 & MTBL & 18011.7 & 1234.33 & $6.85 \%$ \\
\hline 17 & NBL & 37510.29 & 2790.59 & $7.44 \%$ \\
\hline 18 & Southeast & 8341.34 & 815 & $9.77 \%$ \\
\hline 19 & UCBL & 7388.01 & 659.43 & $8.93 \%$ \\
\hline 20 & South Bangla & 6256.8 & 0 & $0.00 \%$ \\
\hline 21 & NRB Commercial & 953.61 & 0 & $0.00 \%$ \\
\hline 22 & Islami & 210634.8 & 2610 & $1.24 \%$ \\
\hline 23 & Al-Arafah & 32837.83 & 2622.52 & $7.99 \%$ \\
\hline 24 & SIBL & 18688.25 & 457.53 & $2.45 \%$ \\
\hline 25 & First Security & 1297.6 & 0 & $0.00 \%$ \\
\hline 26 & Union & 1051 & 0 & $0.00 \%$ \\
\hline
\end{tabular}

Source: Quarterly review, BB 2017

Table 6 represents the amount of total loan disbursement, NPL of those banks have NPL less than $10 \%$. At the end of the second quarter in 2017, 26 banks have classified loan less than 10\%. Southeast Bank has the maximum NPL which was $9.77 \%$. Few banks newly started their operation in Rangpur division that's why they don't have any NPL like Meghna Bank, NRB commercial Bank, First security Islami Bank, Union Bank and South Bangla Agriculture \& commerce bank. RAKUB has the highest amount of NPL and Premier Bank has the 
lowest amount of NPL. Sonali Bank is at the top in terms of amount of NPL which was 24541.00 lac taka.

Table 7: Top ten defaulter's status in terms of Banks classified loan (in lac taka)

\begin{tabular}{|c|c|c|c|c|c|c|}
\hline SN & Name of the Bank & $\begin{array}{c}\text { Total } \\
\text { Outstanding }\end{array}$ & $\begin{array}{c}\text { Total classified } \\
\text { loan }\end{array}$ & $\begin{array}{c}\text { Amount in } \\
\text { Top ten } \\
\text { classified loan }\end{array}$ & $\begin{array}{c}\% \text { (of top } \\
\text { ten } \\
\text { defaulter's) }\end{array}$ & $\begin{array}{l}\% \text { (of non- } \\
\text { performing } \\
\text { loan) }\end{array}$ \\
\hline 1 & Sonali & 271558.00 & 24541.00 & 5943.00 & $2.19 \%$ & $24.22 \%$ \\
\hline 2 & Agrani & 100816.56 & 9712.73 & 3454.26 & $3.43 \%$ & $35.56 \%$ \\
\hline 3 & IFIC & 18210.81 & 1062.20 & 907.04 & $4.98 \%$ & $85.39 \%$ \\
\hline 4 & $\mathrm{AB}$ & 37437.65 & 503.74 & 503.74 & $1.35 \%$ & $100.00 \%$ \\
\hline 5 & One & 5038.81 & 5.07 & 5.07 & $0.10 \%$ & $100.00 \%$ \\
\hline 6 & Trust & 30615.89 & 625.56 & 449.53 & $1.47 \%$ & $71.86 \%$ \\
\hline 7 & DBBL & 4877.63 & 120.11 & 48.28 & $0.99 \%$ & $40.20 \%$ \\
\hline 8 & Brac & 35797.60 & 1399.75 & 412.60 & $1.15 \%$ & $29.48 \%$ \\
\hline 9 & Mercantile & 25385.12 & 998.32 & 543.57 & $2.14 \%$ & $54.45 \%$ \\
\hline 10 & Standard & 43288.62 & 1741.35 & 882.04 & $2.04 \%$ & $50.65 \%$ \\
\hline 11 & Meghna & 4419.49 & 0.00 & 0.00 & $0.00 \%$ & $0.00 \%$ \\
\hline 12 & EBL & 4141.02 & 119.26 & 100.05 & $2.42 \%$ & $83.89 \%$ \\
\hline 13 & Bank Asia & 6938.02 & 302.18 & 299.18 & $4.31 \%$ & $99.01 \%$ \\
\hline 14 & Prime & 13497.95 & 645.19 & 520.79 & $3.86 \%$ & $80.72 \%$ \\
\hline 15 & Uttara & 34806.29 & 3071.38 & 1571.85 & $4.52 \%$ & $51.18 \%$ \\
\hline 16 & MTBL & 18011.70 & 1234.33 & 290.52 & $1.61 \%$ & $23.54 \%$ \\
\hline 17 & NBL & 37510.29 & 2790.59 & 2510.49 & $6.69 \%$ & $89.96 \%$ \\
\hline 18 & Southeast & 8341.34 & 815.00 & 663.49 & $7.95 \%$ & $81.41 \%$ \\
\hline 19 & UCBL & 7388.01 & 659.43 & 642.13 & $8.69 \%$ & $97.38 \%$ \\
\hline 20 & South Bangla & 6256.80 & 0.00 & 0.00 & $0.00 \%$ & $0.00 \%$ \\
\hline 21 & NRB Commercial & 953.61 & 0.00 & 0.00 & $0.00 \%$ & $0.00 \%$ \\
\hline 22 & Islami & 210634.80 & 2610.00 & 1553.50 & $0.74 \%$ & $59.52 \%$ \\
\hline 23 & Al-Arafah & 32837.83 & 2622.52 & 1965.56 & $5.99 \%$ & $74.95 \%$ \\
\hline 24 & SIBL & 18688.25 & 457.53 & 457.53 & $2.45 \%$ & $100.00 \%$ \\
\hline 25 & First Security & 1297.60 & 0.00 & 0.00 & $0.00 \%$ & $0.00 \%$ \\
\hline 26 & Union & 1051.00 & 0.00 & 0.00 & $0.00 \%$ & $0.00 \%$ \\
\hline 27 & Janata & 75089.48 & 8442.53 & 2432.54 & $3.24 \%$ & $28.81 \%$ \\
\hline 28 & Rupali & 64557.62 & 14114.99 & 7489.18 & $11.60 \%$ & $53.06 \%$ \\
\hline 29 & RAKUB & 235743.77 & 64356.67 & 8120.86 & $3.44 \%$ & $12.62 \%$ \\
\hline 30 & Kormoshantan & 8989.54 & 1096.14 & 69.99 & $0.78 \%$ & $6.39 \%$ \\
\hline 31 & Basic & 20918.71 & 10757.07 & 10232.16 & $48.91 \%$ & $95.12 \%$ \\
\hline 32 & BDBL & 12526.62 & 9193.92 & 6233.19 & $49.76 \%$ & $67.80 \%$ \\
\hline 33 & Jamuna & 21106.07 & 2984.91 & 2483.82 & $11.77 \%$ & $83.21 \%$ \\
\hline 34 & The City & 19662.66 & 2817.66 & 2629.67 & $13.37 \%$ & $93.33 \%$ \\
\hline 35 & Dhaka & 13458.91 & 1432.95 & 1260.86 & $9.37 \%$ & $87.99 \%$ \\
\hline 36 & $\mathrm{NCC}$ & 10982.58 & 2243.66 & 1536.85 & $13.99 \%$ & $68.50 \%$ \\
\hline 37 & Pubali & 36071.63 & 5006.08 & 2259.57 & $6.26 \%$ & $45.14 \%$ \\
\hline 38 & Commerce Bank & 2219.76 & 1319.67 & 1319.67 & $59.45 \%$ & $100.00 \%$ \\
\hline 39 & Premier & 2943.00 & 335.96 & 335.96 & $11.42 \%$ & $100.00 \%$ \\
\hline 40 & Shahjalal Islami & 17310.40 & 2537.18 & 2303.94 & $13.31 \%$ & $90.81 \%$ \\
\hline 41 & Exim & 12124.40 & 2662.46 & 1745.62 & $14.40 \%$ & $65.56 \%$ \\
\hline
\end{tabular}

Source: Quarterly review, BB 2017

Table 7 provides the scenario of the top ten defaulters at the end of June 2017. The highest amount of NPL is given by Basic Bank Ltd. to its top ten borrowers which is Taka. 10232.16 lac and $95.12 \%$ and lowest amount given by Karmosangsthan Bank which is Taka.69.99 lac and 6.39\%.

Figures in Table 7 expose the figures of total loan disbursement of banks, amount of classified loan among those disbursements and how much taka is centralized to the top ten defaulters of the banks. It appears that the highest amount of classified loan is given by Sonali Bank Ltd. which is Taka.5943lac and lowest amount is from One bank Ltd. which is Taka.5.07 lac. The highest percentage of credit hold by top ten borrowers of the banks is $100 \%$, that means those banks all classified loan is concentrated to only ten borrowers. Bangladesh Commerce Bank, Premier Bank, AB Bank, One Bank and Social Islami Bank have 100\% credit to their ten borrowers. The classified loan is highest $100 \%$ and lowest is $24.21 \%$ respectively. 


\section{FINDINGS}

Major findings are given below:

- NPL is very high in SOCBs rather than PCBs in Rangpur region (Table-1). Due to have huge number of state-owned commercial banks operating in the study area than the PCBs.

- $\quad$ Recovery rate of SOCBs is lower than PCBs (Table-3).

- Law suit made by SOCBs is very much higher than PCBs but PCBs claims large amount of money against few number of law suit (Table-4).

- SOCBs recovery rate is lower than PCBs (Table-3) due to close supervision among the parties and banks.

- It is seen that top ten large loan defaulter case is lower in SOCBs than PCBs (Table-7). Since PCBs have concentrated to the big borrowers this is why large loan default case is created.

\section{RECOMMENDATIONS}

Banks play vital role in the economy of Bangladesh. Non-performing loan and other obstacles face by banks create barrier to making profit. From this study it was found that $\mathrm{t}$ reasons behind non-performing loans are pressure from political parties, poor monitoring \& controlling system of SOCBs, improper management, concentration on a particular area, improper sanctioning, lack of timely action, delay in disbursement of credit, unwillingness of borrowers etc. On the basis of these problems some recommendations are given by the researcher for mitigating non-performing loan to the commercial banks operating in Rangpur region. Those are given below:

- NPL is comparatively high in SOCBs rather than PCBs. SOCBs management face lots of pressure from political parties. Bank management can't work freely by being appointed by ruling parties. For that reason, few loans are given to the entrepreneurs who are very influential or political persons. These types of loan rarely recovered. Sometimes government gives advice to the SOCBs to distribute loans in specialized sector as their political agenda. These types of loan also rarely recovered. If banks can free from political pressure, default case will decrease in SOCBs.

- Loan recovery is very much important for banks. If banks fail to recover its credit, then banks losses its assets as well as its earnings. PCBs loan recovery status is much higher than SOCBs. This may happen for PCBs management's responsibilities levied by them. PCBs management's responsibilities are much higher than SOCBs managements because PCB's management jobs duration depends on their performance. For that reason, PCBs managements scrutinize all the steps in giving loan from the beginning. It starts from proper borrower selection. It reduces the chance of being defaulted. Second step is Proper documentation. Proper documentation is essential for loan disbursement. Without proper documentation, it is not possible for banks to recover loan by taking legal action. Faulty documentation creates faulty credit line for banks. So documentation must be needed for smooth supervision and efficient lending.

- $\quad$ SOCBs given lots of credit in diversified area compared to the PCBs. This high number of credit makes difficulties for proper supervision and monitoring. Sometimes SOCBs gives very small amount of credit compared to their total loan outstanding. Unfortunately SOCBs management gives less focus to this type of credit. For that reason, this type of credit often being default credit. So SOCBs also gives special focus to all credit like PCBs and try to reduce huge number of credit line.

- For huge number of credits, default cases also in huge in number compared to PCBs. For recovery of those default credits, SOCBs file large number of law-suit but their volume is lower than PCBs. It is very much difficult to operate those law-suit and most of the cases it is not viable.

- Large loan default case is much higher in PCBs than SOCBs. This happens when PCBs managers try to catch a big fish. For fulfilling their yearly target in loan disbursement and profit earnings, they gives loan in higher amount to the another banks customers. Here an unhealthy competition has grown as lots of PCBs newly started but new entrepreneurs are not grown. PCBs should avoid this unhealthy competition and try to find out more reliable entrepreneurs. They should invest in versatile business such as small and cottage industries.

\section{CONCLUSION}

As a small country, Bangladesh already has 57 scheduled banks. There are many non-scheduled banks and financial institutions also operated their businesses. Rangpur, a new division, does not have massive industrialization for its geographic location. Although few new industries has been established but not in large number. In these circumstances, new entrepreneurs are not commencing to start a large scale business. Recently new number of commercial banks have been started their business to disburse big-volume-loan in the study area and searching those kinds of enterprises for lending. Therefore, unhealthy competition begins among the 
managers of PCBs rather than SOCBs as they required to fulfill their yearly targets. Banks should be more cautious in selecting entrepreneurs by scrutinize the previous history and ability. Banks business mostly depends on the smooth recovery of the loan. SOCBs are in deep water by NPL by losing their capital. A very few number of banks NPL are more than $50 \%$. This is alarming for the bank industry. Government tries to keep running banks by injecting fund every year. If PCBs face this problem severely, the situation may be worsening. Necessary precaution, real time solution and sufficient guidelines should be taken for make over the situation. Bangladesh bank can play a vital role in mitigating this problem. Government should have taken positive initiative to make new industries as well as entrepreneurs in Rangpur region so that banks find new opportunities for investment.

\section{References:}

Adhikary, B. K. (2006). Nonperforming loans in the banking sector of Bangladesh: realities and challenges. Bangladesh Institute of Bank Management, 4(26), 75-95.

Afroze, N., \& Uddin, G. M. (2008). Non-Performing Loan and Management Guidelines for Remedies: An Empirical View of Bank Employees.

Ahmed, E., Rahman, Z., \& Ahmed, R. I. (2006). Comperative analysis of loan recovery among nationalized, private and islamic commercial banks of Bangladesh.

Ahmed, S. I. (2006). Banking Sector Performance in Bangladesh (Doctoral dissertation, East West University).

Alam, Nurul M.D. \& Jahan S.B.(1999).Default Loan Culture in the Banking Sector of Bangladesh.Bank Paricrama, 34(4),23-38.

Anjom, W., \& Karim, A. M. (2016). Relationship between non-performing loans and macroeconomic factors with bank specific factors: a case study on loan portfolios-SAARC countries perspective. ELK Asia Pacific Journal of Finance and Risk Management, 7(2), 1-29.

Bangladesh Non Performing Loans Ratio [2003 - 2020] [Data \& Charts]. (2020). Ceicdata.com. Retrieved 9 January 2020, from https://www.ceicdata.com/en/indicator/bangladesh/non-performing-loans-ratio

Banik, B.P. \& Das, P.(2015).Classified loans and Recovery Performance: A comparative study between SOCBs and PCBs in Bangladesh. The cost and Management Journal,43(3), 20-24

Causes of non-performing loan and effects on banking sector | daily sun. (2020). Daily Sun. Retrieved 9 January 2020, from https://www.daily-sun.com/post/311639/2018/05/27/Causes-of-nonperforming-loan-andeffects-on-banking-sector

Choudhury, T. A., \& Adhikary, B. K. (2002). Loan Classification, Provisioning Requirement and Recovery Strategies: A comparative Study on Bangladesh and India. In Seminar Paper, Bangladesh Institute of Bank Management, January (pp. 21-54).

Chowdhury, R., \& Dhar, B. K. (2012). The Perspective of Loan Default Problems of the Commercial Banking Sector of Bangladesh: A Closer look into the Key Contributory Factors. University of Science and Technology Annual (USTA), 18(1), 71-87.

Emran, M. (2019). The economic consequence of non-performing loans. The Daily Star. Retrieved 9 January 2020, from https://www.thedailystar.net/opinion/economics/news/the-economic-consequence-nonperforming-loans-1797394

Faruk, M. O., \& Islam, M. S. (2016). An Analytical Review of Non-Performing Loan: Bangladesh and Global Perspectives. In Annual Banking Conference 2015.

Hassan \& Reza .(1997).Efficiency Through Competition: Comparison of commercial Banks. Journal of Business Studies, DU,16(1), 113-130.

Hassan, K. (1994). The financial sector reform of Bangladesh. Thoughts on Economics, 3(1-2), 40-64.

Hou, Y., \& Dickinson, D. (2007, August). The non-performing loans: some bank-level evidences. In 4th International Conference on Applied Financial Economics, Samos Island, Greece.

Islam, A. (2019). Effectiveness of alternative dispute resolution on the recovery of non-performing loans under Artha Rin Adalat: A study on nationalized commercial banks in Bangladesh (Doctoral dissertation, University of Dhaka).

Islam, M. S., Shil, N. C., \& Mannan, M. (2005). Non performing loans-its causes, consequences and some learning.

Khan, S. A., \& Farooqi, Q. G. M. (2011). Implication of the Legal Framework Guiding Loan Recovery. Banking Research Series 2011, 287-300.

Majumder, D. (2014). Non-performing loans in banking sector of Bangladesh: causes and effect.

Moti, H. O., Masinde, J. S., Mugenda, N. G., \& Sindani, M. N. (2012). Effectiveness of credit management system on loan performance: empirical evidence from micro finance sector in Kenya. International Journal of Business, Humanities and Technology, 2(6), 99-108.

Mujeri, M. (2018). Rising non-performing loans. The Daily Star. Retrieved 9 January 2020, from https://www.thedailystar.net/news/opinion/perspective/rising-non-performing-loans-1619257 
Nimalathasan, B. (2008). A comparative study of financial performance of banking sector in Bangladesh. An application of CAMELS rating system. Universitatii Bucuresti. Analele. Seria Stiinte Economice si Administrative, 2, 133.

Non-performing loans in our banking sector | daily sun. (2020). Daily Sun. Retrieved 9 January 2020, from https://www.daily-sun.com/printversion/details/417862/2019/08/25/Nonperforming-loans-in-our-bankingsector

Parven, S. (2011). Nonperforming loans of commercial banks in Bangladesh.

Pasricha, A. S. (2007). On Financial Sector Reform in Emerging Markets: Enhancing Creditors' Rights and Securitizing Non-Performing Loans in the Indian Banking Sector-An Elephant's Tale. Buff. L. Rev., 55, 325.

Podder, J., \& Al Mamun, A. (2004). Loan loss provisioning system in Bangladesh banking: A critical analysis. Managerial Auditing Journal, 19(6), 729-740.

Publication. (2020). Bb.org.bd. Retrieved 8 January 2020, from https://www.bb.org.bd/pub/

Rajan, R., \& Dhal, S. C. (2003). Non-performing loans and terms of credit of public sector banks in India: An empirical assessment. Reserve Bank of India Occasional Papers, 24(3), 81-121.

Siddiqua, M. A., \& Zaman, M. N. Loan Recovery and Performance of Commercial Banks: A Study on Jamuna Bank Limited (JBL) \& Janata Bank Limited (JB).

Sikder,Alam \& Alam Z. (2006). A Study of the Operational Performance of Bangladesh Krishi Bank.Journal of Business Administration, IBA,DU,32(1,2),139-153

Surge in non performing loans in banking sector: Learning from neighboring countries on combating NPL. (2020). Idlc.com. Retrieved 9 January 2020, from https://idlc.com/mbr/article.php?id=167

Woo, M. D. (2000). Two approaches to resolving nonperforming assets during financial crises. International Monetary Fund. 